\title{
STUDI ANALISIS MENGENAI PERTALIAN STRUKTUR AMSAL 10:1-5 SEBAGAI PERAN ORANG TUA DALAM PEMBENTUKAN KARAKTER ANAK
}

\author{
Farel Y. Sualang, M.Th* \\ Email: Sualangfare1@gmail.com \\ Sekolah Tinggi Teologi Injili Indonesia, Yogyakarta
}

\begin{abstract}
Abstrak
This article discusses the analysis of the structural strings in Proverbs 10:1-5 as the role of parents in the formation of children's character. The purpose of this article is to interpret Proverbs 10: 1-5 and give attention to the bridge of the context of Proverbs 1-9 about the role of parents in forming a child's character. The author uses Wisdom Genre Hermeneutics as a procedure in research, so found 4 major conclusions in making this scientific work. First, the character formation of a child always begins with the role of parents in providing the educational process. The key to affinity Structure Proverbs 10:1-5 which provides a transition / hinge in the fundamentals of wisdom Proverbs 1-9, giving the author directions that the results of the quality of the wise child cannot be separated from the education of parents. This needs to be known where the process of education in the family also continues to apply in the midst of the life of the Israelites, even in the royal period, especially in the time of his own exile. Second, the role of parents in education seems to be carried out in a balanced manner, namely father and mother. Proverbs 10: 1 explains that the character quality of a child will have consequences for the judgment of a father and mother. The teacher of wisdom is not only to a father, but also to a mother. Therefore, education in the family is carried out by a team, namely father and mother (see Context Proverbs 4: 1; 6:20; etc.). Third, the writer of Proverbs teaches that a child can have wise character qualities. The wise character quality of children is obtained from parental education. Through the study of the author in Proverbs 10:1-5, wise children are educated in moral teachings that are based on the teachings of God (Old Testament context). In addition, the educational process is also based on good experience of the life of a father and mother, so that a child can imitate the habits / good qualities of his parents, moreover the wise nature emphasized in Proverbs 10: 1-5 is the nature of honesty (v. 3) and perseverance (vv. 4-5) as an identity of a minded person. And fourth, the action or character shown to a child can be an evaluation for parents of the teachings of wisdom that have been conveyed (Band. Teachings of wisdom in Proverbs 10:1), so that in the future they can teach again the teachings of wisdom for a person children, so that one day they can become wise children.
\end{abstract}

Key words: Character Formation, Parents role, Wisdom Hermeneutics, strings structure.

\section{Pendahuluan}

Pembentukan karakter biasanya didasarkan pada kehidupan manusia yang membentuk suatu susunan, yaitu: tindakan, pengaruh dan tanggung jawab. Serta, merefleksikan suatu kecenderungan untuk bertindak, merasakan dan berpikir pada beberapa kebiasaankebiasaan yang dilakukan. ${ }^{1}$ Hasil terhadap karakter sangat ditentukan oleh banyak faktor utama,

* FAREL YOSUA SUALANG, M.TH (STTII Yogyakarta) adalah seorang dosen dan mahasis wa doktoral di Sekolah Tinggi Teologi Injili Indonesia, Yogyakarta. 
seperti, lingkungan masyarakat, keuputusan dan perbuatan seseorang, instruksi moral (teguran bijak) dan terlebih khusus peran orang tua.

Dari sudut pandang pemahaman secara biblika, kitab Amsal juga menekankan pembentukan karakter yang berpusat kepada lingkungan keluarga. Dave Bland dalam artikelnya The Formation of Character in the Book of Proverbs menganggap bahwa pembentukan karakter yang mendasar berasal dari peran orangtua. ${ }^{2}$ Konteks historis Israel sangat menekankan kepada peran keluarga dalam pembentukan karakter yang tercatat dalam kitab Amsal. Menurut Dave Bland, kitab Amsal dibingkai dalam suasana (setting) kekeluargaan. Hal ini dapat diperhatikan dalam bagian-bagian strukur kitab Amsal. Pada bagian permulaan, Jika memperhatikan konteks sesudah dalam Amsal 1: 1-7, nasihat bijak yang pertama menjelaskan: "Hai anakku, dengarkanlah didikan ayahmu, dan jangan menyia-nyiakan ajaran ibumu'(1:8-9). Selain itu, bagian pertengahan dalam kitab Amsal yaitu pasal 10: 1-22:16, juga dimulai dengan suatu nasehat yang berhubungan antara seoarang anak kepada orang tuanya: "Seorang anak yang bijaksana membuat ayah yang bahagia, tetapi anak yang bodoh adalah kesedihan seorang ibu "(10:1) dan terakhir juga menjelaskan tentang gambaran dari rumah yang tertata rapi dan penasihat wanita yang cakap (31: 10-31). Dia adalah orang yang "membuka mulutnya dengan hikmat, pengajaran yang lemah lembut ada di lidahnya" (31:26). Jika memperhatikan penjelasannya di atas, maka kunci utama dalam dasar pembentukan karakter seseorang dapat diperoleh melalui pendidikan dari komunitas yang kecil yaitu keluarga. ${ }^{3}$

Menurut penulis dalam pengerjaan tesis yang berjudul "Studi Analisis dan Sintesis mengenai Pembentukan Karakter melalui Harta dalam Amsal 10:1-22:16" juga menemukan bahwa salah salah satu dari lima faktor penting pembetukan karakter adalah faktor Lingkungan, dimana terdiri dari faktor keluarga (perang orangtua) dan lingkungan sosial (komunitas masyarakat). ${ }^{4}$ Sifat-sifat bijak yang dimiliki oleh seseorang sebenarnya merupakan warisan (pembawaan) dari ayah, ibu ataupun nenek moyangnya. Penulis Amsal juga menjelaskan bahwa pembentukan karakter terhadap harta dapat mewariskan setiap prinsip-prinsip, ajaran-ajaran ataupun didikan moral kepada anak cucunya (13:24). ${ }^{5}$ Dengan demikian, orang tua akan mendidik anak-anaknya dengan memberi, ataupun berhemat secara bijak, supaya para orang tua dapat meninggalkan pengajaran-pengajaran moral yang baik kepada anak-anaknya nanti. Pembentukan karakter terhadap pengelolaan harta tidak lepas dari peran orang tua ataupun sanak saudaranya yang memberikan didikan dan pengajaran, sehingga sikap/perilaku seseorang memiliki kesamaan dengan karakter baik dari orang tuanya. ${ }^{6}$

Dari sudut pandang ilmu psikologi, peran keluarga merupakan bagian utama dalam pembentukan karakter anak. ${ }^{7}$ Seperti pemahaman psikolog modern Thomas Licona juga menjelaskan bahwa keluarga (keluarga inti yaitu ayah-ibu) adalah lingkungan pertama di mana

\footnotetext{
${ }^{1}$ William P. Brown, Character in Crisis: A Fresh Approach to the Wisdom Literature of the Old Testament (Grand Rapids: Wlliam B. Eerdmans Publishing, 1996), 6.

${ }^{2}$ Dave Bland, "The Formation of Character in The Book of Proverbs," Restoration Quarterly Jil. 40 (1998), 221-237.

${ }^{3}$ Ibid.

${ }^{4}$ Farel Y. Sualang, "Studi Analis is dan Sintesis dalam Pembentukan Karakter melalui Harta menurut Amsal 10:1-22:16.” M.Th. Tes, Sekolah Tinggi Teologi Injili Indonesia Yogyakarta, 1985, 130-131.

${ }^{5}$ Ris nawaty Sinulingga, Tafsiran Alkitab: Amsal 10:1-22:16 (Jakarta: Gunung Mulia, 2012), 153.

${ }^{6}$ Setiawani, Stephen Tong, Seni membentuk karakter Kristen (Surabaya: Momentum, 2014), 37.

${ }^{7}$ Doni Koesoema, Pendidikan Karakter Utuh dan Menyeluruh (Yogyakarta: Kanisius, 2015), 146-151. Muchlas Samani, Hariyanto, Konsep dan Model Pendidikan Karakter (Bandung: Remaja Rosdakarya, 2017 ), 20.
} 
manusia sejak dini belajar mengenai tata nilai atau moral. ${ }^{8}$ Atas dasar kajian-kajian bilblika dan sudut pandang pengetahuan umum mengenai faktor pembentukan karakter dalam keluarga, penulis perlu menganalisa suatu teks yang mendasar secara biblika mengenai pertalian Struktur (string structure) Amsal 10:1-5 mengenai kepentingan Peran orang tua dalam pembentukan karakter.

\section{Komentar-komentar Teks Amsal 10:1-5}

Kitab Amsal berisi tentang topik-topik yang umum, tetapi seringkali amsal-amsal tersebut bersambung dari satu topik ke topik yang lain tanpa hubungan jelas diantaranya. Misalnya, dalam Amsal 10:1-5, ayat pertama berbicara mengenai anak-anak bijaksana dan anakanak bodoh, ayat kedua, berbicara tentang "harta yang diperoleh dengan kefasikan," ayat ketiga, mengenai kelaparan, sedangkan ayat keempat dan kelima mengenai kemalasan. ${ }^{9}$ Sekalipun adanya perbedaan antar penekanan topik dalam Amsal-Amsal Salomo, Namun masih ada hubungan-hubungan kata, frase dan kalimat yang memberikan potensi pertalian struktur (String Structure) antar Amsal. ${ }^{10}$ Hal yang sama, para penafsir pun diharuskan memperhatikan setiap bagian yang menjadi potensi hubungan secara struktur yang bertangga. contohnya bisa diperhatikan skema di bawah ini.

\section{0 hal yang harus diperhatikan dalam menafsirkan kitab Amsal \\ Kumpulan-kumpulan Amsal (Collections) \\ Bagian/Pemenggalan Amsal (Section)}

Syair (Poems)

Bait Amsal (Stanza)

Pasangan Amsal (Proverb Pairs)

Barisan ayat (Lines)

Bagian kalimat/ayat (Versets)

Frase (Phrases)

Kata (Words)

Suku Kata (Syllables)

\footnotetext{
${ }^{8}$ Thomas Licona, Character Matters: How to Help Our Children Develop Good Judgement, Integrity, and other essential virtues (Jakarta: Bumi Aksara, 2012), 50-51.

${ }^{9}$ Tremper Longman III, Making Sense of the Old Testament (Malang: Literatur SAAT, 2012), 29.

${ }^{10}$ Bruce Waltke, The Book of Proverbs Chapters 1-15 (Michigan: William B. Eerdmans, 2004), 114.
} 
Suara (Sound)

Oleh sebab itu, dalam mengkaji "pertalian struktur Amsal 10:1-5 sebagai bentuk ajaran orang tua kepada anak dalam pembentukan karakter," penulis akan menggunakan metode Hermeneutika Genre hikmat dengan memakai analisis konteks, analisis teologis. Namun begitu, penulis sangat berorientasi untuk menginterpretasi ayat-ayat ini dengan analisis terjemahan dan analisis Struktur. ${ }^{11}$

\section{Komentar Amsal 10:1}

Dalam ayat ini, Raja Salomo menulis betapa pentingnya peran orang orangtua untuk mendidik anak-anaknya agar menjadi orang yang bijak sebagai pola dalam pembentukan karakter. Penulis akan memaparkan 2 (dua) analis is yaitu ansalisa Terjemahan dan Analisa Struktur untuk memahami Amsal $10: 1$.

Analisa Terjemahan dan Catatan Teks

\begin{tabular}{|c|c|}
\hline Teks Ibrani & Terjemahan Teks \\
\hline 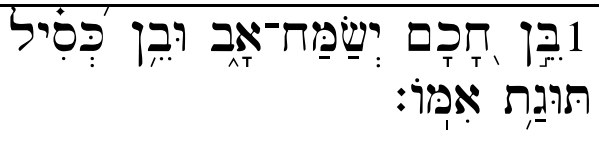 & $\begin{array}{l}\text { 1. Anak-anak yang bijak membuat } \\
\text { seorang ayah bersukacita, tetapi anak } \\
\text { yang bebal mendukakan ibunya. }\end{array}$ \\
\hline
\end{tabular}

Menurut penulis ada 2 (dua) catatan teks yang penting dalam Amsal 10:1. Pertama, kata $\square \supset_{T} \prod_{T}$ “hākām” yang diartikan sebagai "bijak." Kata ini menunjukan suatu sifat dari anakanak yang membuat seorang ayah bersukacita. Kata $\beth_{T} \prod_{T}$ " "ḥākām” merepresentasikan cara berpikir, sikap tentang pengalaman hidup, dasar moralitas yang bersumber kepada ajaran Tuhan (Perjanjian Lama). Namun begitu, sifat-sifat bijak tersebut diterapkan dalam banyak kehidupan praktis. ${ }^{12}$ Dalam hal ini, "Anak-anak yang bijak" memberikan suatu moralitas yang baik, sifatsifat bijak yang diwujudkan dalam kebiasaan-kebiasaan dalam kehidupannya, sehingga orang tua sangat berbahagia kepada anaknya.

Bagian dari ayat $1 \mathrm{~b}$ memberikan suatu dasar sistem kekerabatan dimana adanya ketergantungan pada semua anggota keluarga di tengah-tengah masyarakat Israel Kuno. ${ }^{13}$ Kalimat hikmat ini menyebutkan tiga anggota keluarga, yaitu "anak," "bapa," dan "ibu." Dalam masyakarat ini, kehidupan bapa dan ibu sangat tergantung dari anak tersebut, demikian pula

11 Roland E. Murphy, Word Biblical Commentary-Volume 22-Proverbs (Colombia: Thomas Nels on Publishers, 1998), 23. Michael Fox, Proverbs 10-31: A New Translation With Introduction And Commentary (New Haven: Yale University, 2009), 493-494, Duane A. Garrett, The New American Commentary:An Exegetical and Theological Exposition of Holy Scripture Proverbs, Ecclesiastes, Song of Songs (Nashville: Broadman \& Holman Publishers, 1993), 9-25, Farel Y. Sualang, Pistis: Prinsip-Prinsip Hermeneutika Genre Hikmat dalam Kitab Amsal: Suatu Pedoman Eksegesis, Vol: 17, no: 3(2017), 93-112.

${ }^{12}$ R. Laird Harris, Gleas on L. Archer, Jr., Bruce K. Waltke, Theological Wordbook of the Old Testament (Chicago: Moody Press, 1981), 647.

${ }^{13}$ R. D. Vito, "Old Testament Anthropology and the Construction of Personal Identity" Catholic Bibliqal Quaterly 61 (1999), 221. Duane A. Garrett, The New American Commentary:An Exegetical and Theological Exposition ofHoly Scripture Proverbs, Ecclesiastes, Song of Songs, 117. 
sebaliknya, ${ }^{14}$ terutama anak laki-laki yang akan mewakili keluarganya dalam masyarakat. Tema mengenai "Anak yang bijak membuat seorang ayah yang bersukacita" adalah hal yang umum dalam kitab Amsal, tema yang sama juga ditemukan dalam 17:21, 25; 23:24-25; 28:7; 29:3.

Kedua, istilah Ibrani untuk "anak yang bebal” memakai kata Ibrani yang menekankan kepada esensi terhadap anak yang bebal, seperti: seorang anak yang membenci pengetahuan, menyenangi kebodohan, kesalahan, bahkan berorientasi untuk terusmenerus mengalami pertumbuhan dalam sikap-sikap tingkah laku yang negatif. ${ }^{15}$ Bahkan, C. H. Toy juga menjelaskan bahwa istilah anak yang bebal dalam Amsal 10:1 memberikan pengertian kepada seorang anak yang sangat membenci didikan, kritikan dan pengetahuan, bahkan menyenangi suatu kesalahan dan kejahatan sebagai suatu karakter ataupun gaya hidup. ${ }^{16}$ Oleh sebab itu, Anak bebal ini akan mendukakan lingkungan keluarga (orang tua dan saudarasaudaranya) dan lingkungan masyarakat.

\section{Analis is Struktur}

Amsal 10:1 menampilkan pola dua baris (distich), dimana Stich A dan Stich B memiliki bentuk paralelisme antitesis (kontras). ${ }^{17}$ Dari sisi yang lain, Amsal ini membentuk hubungan-hubungan struktur antar frase dari ayat 22, dengan memakai model a-a'-b-b' ${ }^{18}$ Hal tersebut dapat diperhatikan pada tabel dibawah ini.

\begin{tabular}{|c|c|}
\hline \multicolumn{2}{|l|}{ Analisis Struktur Amsal 10:1 } \\
\hline Stich A- Anak yang bijak & (frase a) \\
\hline Membuat seorang Ayah bersukacita & (frase a') \\
\hline \multicolumn{2}{|l|}{ Tetapi } \\
\hline Stich B- Anak yang bebal & (frase $b$ ) \\
\hline Mendukakan Ibunya & (frase $b^{\prime}$ ) \\
\hline
\end{tabular}

Antites is dalam ayat ini dapat dibagi menjadi 3 (tiga) bagian. Pertama, antitesis antara frase a

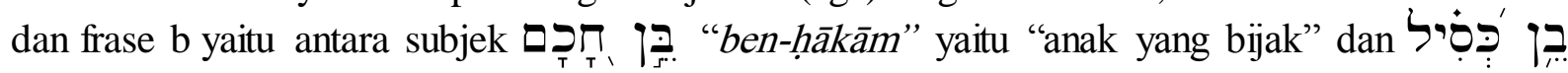
"ben- $k^{e}$ Sîl” yaitu "anak yang bebal." Kedua subjek ini dikontraskan oleh Raja Salomo untuk menunjukan perbedaan yang sangat tajam antara seorang anak yang mempunyai sifat bijak dan seorang anak mempunyai sifat bebal, seperti yang dijelaskan oleh penulis di atas dalam catatan

${ }^{14}$ Dalam bagian lain ditemukan kebahagiaan keluarga yang ditentukan oleh orang tua dan anak $(15: 20 ; 17: 21,25 ; 19: 13,26 ; 23: 22-26)$ atau oleh suami dan istri $(12 ; 4 ; 14: 1 ; 18: 22 ; 19: 14 ; 21: 9,19)$.

${ }^{15}$ Francis Brown, S. R. Driver, dan Charles A. Briggs, A Hebrew And English Lexicon of the Old Testament (Oxford: Clarendon Press, 1980), 493.

${ }^{16}$ C. H. Toy, Critical and Exegetical Commentary on the Book of Proverbs (Edinburgh: T\&T Clark, 1904), 197.

17 Allen P. Ross, The Expositor's Bible Commentary (Michigan: Zondervan, 2008), 113.

${ }^{18}$ Roland Meynet, Rethorical Analysis: An Introduction to Biblical Rhetoric (Sheffield: Sheffield Academic Press, 1998), 231. 
teks. Kedua, antitesis antara frase a'-b' yaitu antara "membuat seorang ayah bersukacita" dan "mendukakan ibunya." Kedua frase ini adalah hasil ataupun konsekuensi dari kedua sifat anak (anak bijak dan anak bebal). Ketiga, yaitu ayah dan ibu. Topik ayah dan ibu yang dipertentangkan memperlihatkan dimana pentingnya orangtua (ayah dan ibu) yang harus berperan seimbang dalam mendidik anak. Oleh sebab itu, inilah yang ditekankan dalam kitab Amsal dimana proses pembentukan karakter seseorang sangat dipengaruhi oleh institusi kecil yaitu keluarga.

Jika memperhatikan penjelasan paragraf di atas, maka ayat ini memakai tipe dengan model perkataan karakter-konsekuensi. ${ }^{19}$ Patut untuk diperhatikan bahwa frase a'-b' merupakan konsekuensi/dampak dari karakter seorang anak yang bijak dan bebal. Contoh dapat diperhatikan pada tabel di bawah ini.

\begin{tabular}{|c|c|c|c|c|}
\hline \multicolumn{5}{|c|}{ Tipe perkataan tindakan-konsekuensi Amsal 10:1 } \\
\hline Stich & Frase & Karakter & Frase & Konsekuensi \\
\hline A & a & Anak yang bijak & a' & Membuat seorang Ayah bersukacita \\
\hline B & b & Anak yang bebal & b' & Mendukakan Ibunya \\
\hline
\end{tabular}

Artinya bahwa hasil karakter dari seorang anak akan memberikan suatu respon kepada orang tuanya. Respon ini bisa berupa baik ataupun buruk. Nampaknya, penulis Amsal juga menunjukan kepada pembacanya bahwa keterkaitan pangajaran orang tua kepada anak akan membuat suatu respon balik kepada orang tua (band. Konteks Pengajaran hikmat orangtua kepada Anak dalam Amsal 4). Hal ini disebabkan oleh tindakan ataupun karakter yang ditunjukan oleh anak tersebut, sehingga orangtua dapat mengevaluasi ajaran-ajaran yang telah disampaikannya dan mengajarkan kembali kepada anaknya.

Pengajaran orang tua kepada anak dan konsekuensinya

${ }^{19}$ Brent Sandy, Ronald L. Giese, Jr, Cracking Old Testament Codes: A Guide Interpreting the Literary Genres of the Old Testament (Nashville: Broadman \& Holman Publishers, 1995), 236. 


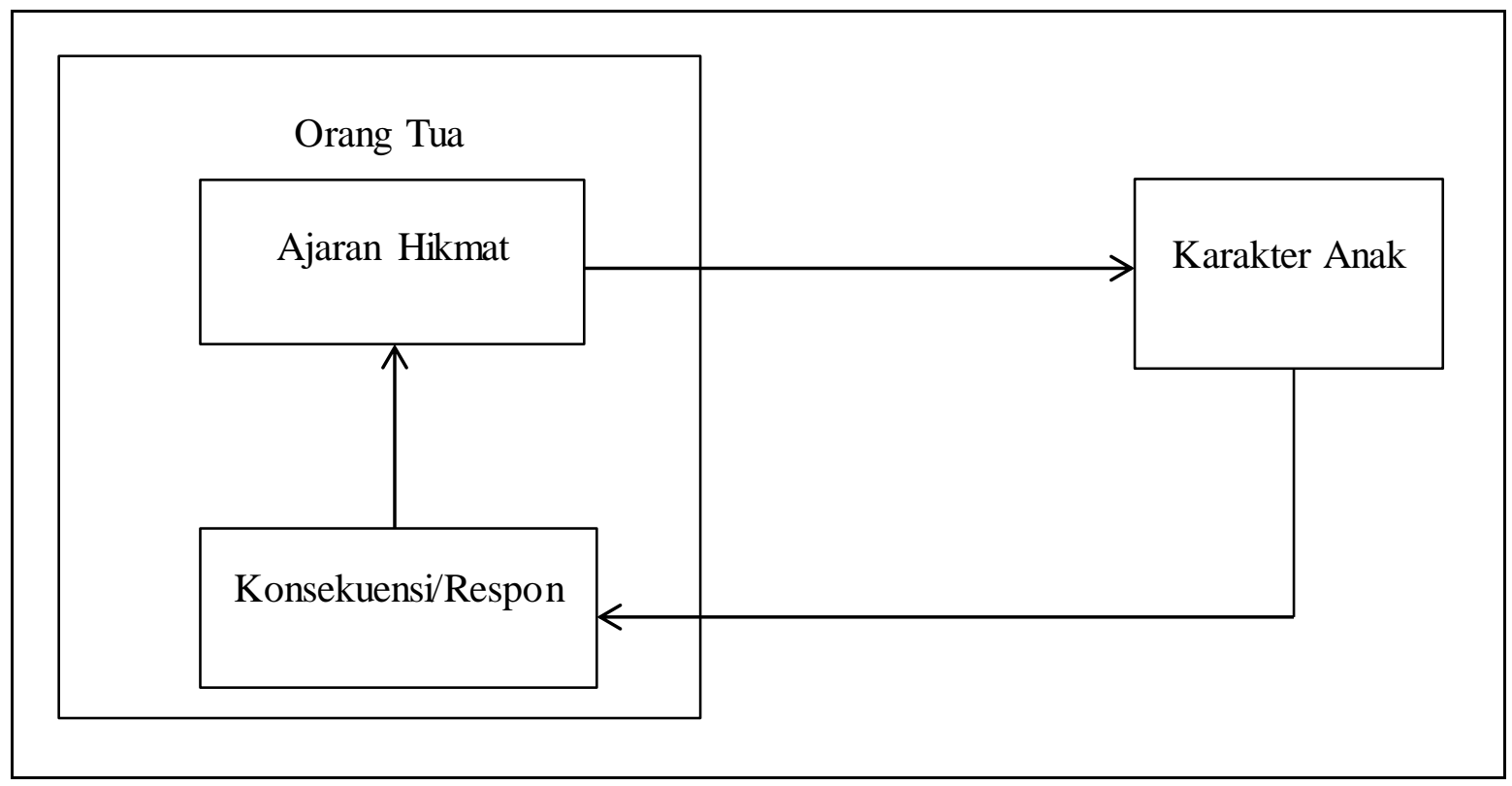

Kesimpulan Teks Amsal 10:1

Pengajaran dalam Amsal 10:1 merupakan hal yang sangat penting, dimana sifat/karakter anak memberikan suatu kebahagian bagi orangtuanya. Sedangkan, orangtua yang anaknya bebal, akan dipenuhi dengan kesusahan, kekecewaan, kekecemasan karena tingkah laku dan nama baik anaknya yang jelek. Bahkan, nama baik anak tersebut akan menentukan keberlanjutan hidup suatu keluarga dan status sosialnya dalam masyarakat, dimana berpengaruh terhadap keluarga dan generasi selanjutnya dalam masyarakat.

Jika kembali memperhatikan tabel di atas, maka ayat ini juga berfungsi sebagai suatu dorongan bagi orangtua untuk mendidik anaknya menjadi bijak bukan anak bebal. Oleh sebab itu, Amsal 10:1 memberikan sifat-sifat bijak (virtue) yang mengarahkan seorang anak untuk hidup berhikmat. Tidak heran betapa pentingnya penekanan anak yang hikmat dalam kitab Amsal, selain tema utama kitab ini yaitu hikmat, namun juga menekankan pendidikan anak yang berasal dari orang tua berdasarkan Amsal 4. Mungkin hal tersebut bisa dikatakan sebagai setting of life dimana pusat materi pendidikan adalah keluarga.

\section{Komentar Amsal 10:2-3}

Raja Salomo memaparkan satu cara yang begitu penting dalam pembentukan karakter terhadap harta, yaitu: kejujuran. Kedua ayat ini memiliki sesuatu hubungan dan tujuan yang sama, terlebih dalam ayat ketiga memberikan beberapa alasan-alasan dari ayat sebelumnya mengenai pentingnya kejujuran dalam membentuk karakter terhadap harta. ${ }^{20}$ Karakteristik dari ayat ini akan dijelaskan oleh penulis dalam beberapa analis is seperti berikut. ${ }^{21}$

\section{Analisis Terjemahan dan Catatan Teks}

${ }^{20}$ Matthew Henry, Tafsiran Matthew Henry: Kitab Amsal (Surabaya: Momentum, 2013), 188.

${ }^{21}$ Artikel ini telah ditulis oleh Penulis dalam menganalisa sifat kejujuran menurut Amsal 10:2-3 dalam Jurnal Pistis. Farel Y. Sualang, "Analisa Sifat Kejujuran sebagai suatu Pembentukan Karakter menurut Amsal 10:2-3,” Pistis: Jurnal Teologi Injl,i Jil. 1, no. 2 (2017): 59-81 . 


\begin{tabular}{|c|c|}
\hline Teks Ibrani & Terjemahan Teks \\
\hline 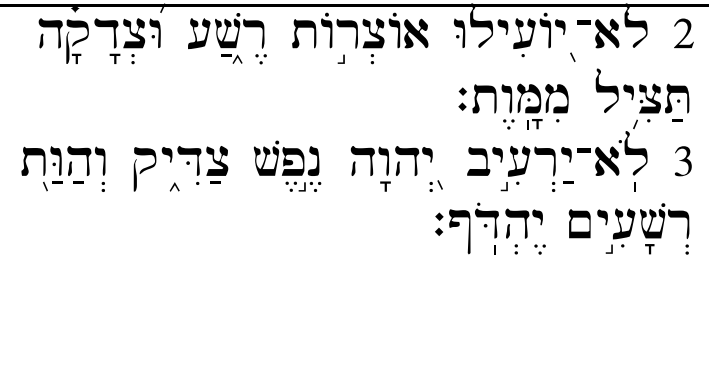 & $\begin{array}{l}\text { 2. (bagian A) Harta benda kefasikan tidak } \\
\text { akan menguntungkan, tetapi } \\
\text { (bagian B) kebenaran akan menyelamatkan } \\
\text { dari kematian } \\
\text { 3. (bagian A) Tuhan tidak akan membuat } \\
\text { jiwa orang yang benar menderita kelaparan, } \\
\text { tetapi (bagian B) Ia menolak keinginan } \\
\text { orang-orang fasik. }\end{array}$ \\
\hline
\end{tabular}

Pada ayat kedua, penulis akan memberikan 4 (empat) catatan teks yang begitu

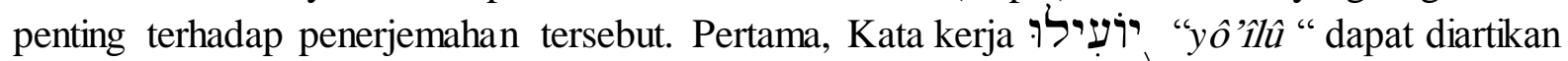
sebagai "menguntungkan, bermanfaat ataupun berguna." 22 Kata kerja ini menjelaskan tentang

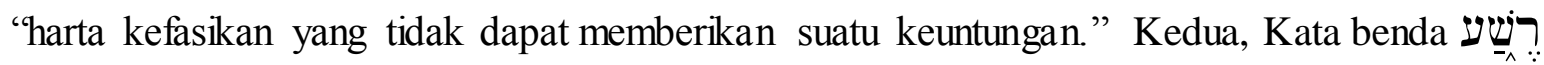
"reša" diartikan sebagai "kefasikan, kejahatan dan kriminal. Kata tersebut dapat memberikan arti pada 2 (dua) aspek: 1) bertindak secara licik, 2) mengutuk sebagai suatu kesalahan. ${ }^{23}$ Dari hubungan kalimat ini, kata kefasikan lebih mengarah kepada suatu tindakan atau cara-cara yang dilakukan secara licik. Dari baris pertama ayat ini, kefasikan memiliki arti sebagai suatu tindakan yang licik terhadap harta yang diperoleh. Tindakan licik tersebut merupakan hal yang tidak menguntungkan, bahkan tidak memiliki nilainya sama sekali.

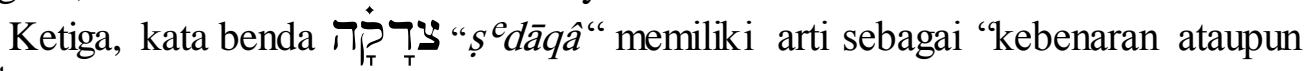
keadilan."24 Arti dari kata "kebenaran" biasanya merujuk kepada karakteristik atau sifat Allah yang merupakan dasar dari kehendak atau kemauanNya sendiri. ${ }^{25}$ Bahkan menurut Snaith, kata ini dapat diartikan sebagai suatu etika atau penilaian-penilaian moral tertentu. ${ }^{26}$ "Kebenaran" dapat merujuk kepada suatu tindakan/ekspresi yang benar dan adil. ${ }^{27}$ Dalam ayat kedua, kebenaran ini akan menyelamatkan dari kematian. Perlu diperhatikan, bahwa dalam bahasa Ibrani tidak mempergunakan kata yang bermakna "orang" (seperti dalam bahasa Indonesia: "kebenaran menyelamatkan orang...") sesudah kata "menyelamatkan." Jadi, lebih baik menerjemahkannya tanpa mencatumkan kata orang. ${ }^{28}$

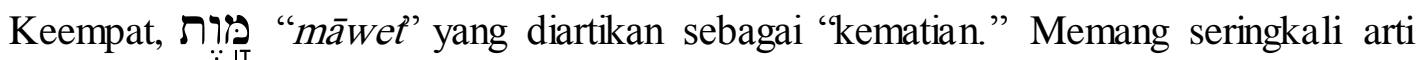
dari kata ini secara harafiah lebih mengarah kepada kematian secara jasmani. ${ }^{29}$ Namun, penulis lebih menyutujui apa yang dipaparkan oleh Roland Murphy, bahwa penggunaan kata "māwet' di bagian Perjanjian Lama yang lain, makna kematian dalam ayat ini mencakup pada situasi yang sulit dan sengsara, karena transaksi bisnis yang akan mendatangkan hukuman atas

\footnotetext{
${ }^{22}$ Kata kerja hifil imperfek 3 maskulin jamak. John J. Owens, Analytical Key to the Old Testament (Grand Rapids: Baker Books, 2000), 545.

${ }^{23}$ R. Laird Harris, Theological Wordbook ofthe Old Testament (Chicago: Moody Press, 1981). Bibleworks 9. Copyright $\odot 2011$ bibleworks, LLC Version 9.0.

${ }^{24}$ William L. Holladay, A Concise Hebrew And Aramic Lexicon of the Old Testament (Grand Rapids: Eerdmans; Leiden: Brill, 1988), 303.

${ }^{25}$ TWOT. Bibleworks 9. Copyright @ 2011 bibleworks, LLC Version 9.0.

${ }^{26}$ Ibid.

${ }^{27}$ Sinulingga, Tafsiran Alkitab: Amsal 10:1-22:16, 47.

${ }^{28} \mathrm{Ibid}, 37$.

${ }^{29} \mathrm{Ibid}$.
} 
dirinya sendiri. $^{30}$ Tentunya, pembicaraan pada ayat kedua akan memberikan arti yang penuh apabila memperhatikan kepada analis is selanjutnya yang berkaitan dengan konteks amsal dan hubungan paralelismenya dengan ayat ketiga.

Pada ayat ketiga, ada 2 (dua) kata yang diambil oleh penulis untuk memberikan catatan teks dalam ayat ini. Pertama, kata נקפּ: "nefeš " yang dapat diartikan sebagai "jiwa,

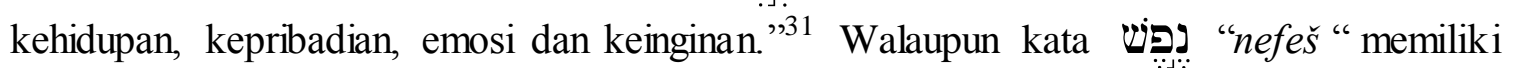
banyak arti, tetapi penulis lebih merujuk untuk menerjemahkan kata ini dengan "jiwa." Kata ini juga dapat diartikan sebagai kesatuan emosi, dasar pemikiran dan kepribadian seseorang, bahkan mengarahkan kepada keinginan yang besar (nafsu) dan keinginan-keinginan lainnya. ${ }^{32} \mathrm{Jika}$ memperhatikan beberapa terjemahan, baik ARSV dan ERV memberi terjemahan "jiwa" sebagai maksud dari ayat ketiga. Penulis memperhatikan bahwa konteks dari kata נִִּּ "nefeš " " memberikan suatu antitesis dari "keinginan orang-orang fasik" (ay.3b), karena "jiwa orang benar" akan dipelihara oleh Tuhan, sedangkan "keinginan orang-orang fasik" akan ditolakNya. Tampaknya, kedua keinginan (hasrat) orang tersebut merupakan respon Allah terhadap setiap tindakan yang diperoleh secara fasik maupun secara kebenaran dari ayat kedua.

Kedua, kata הַּ: "hawwât." Kata ini diartikan sebagai "keinginan ataupun hasrat."33

Walaupun begitu, kata Ibrani ini memiliki banyak arti dan penyebutan yang hampir sama. Kata הַ: ה"haWwâ" seringkali juga diartikan sebagai "bencana dan kejatuhan." Namun dari sisi lain, kata yang dipakai dalam ayat ketiga ini diambil dari kata dasar הְַּּ "hawwâ" diartikan sebagai "keinginan ataupun hasrat," meskipun hampir memiliki kesepadanan dengan kata sebelumnya. ${ }^{34}$ Hal ini dapat diperhatikan dengan terjemahan-terjemahan lain seperti NIV, ARSV dan TIB yang menerjemahkan kata "hawwât" sebagai "keinginan ataupun hasrat." Sehingga kata ini sesuai dengan apa yang diterjemahkan oleh penulis bahwa, "Allah menolak keinginan orang-orang fasik."

Analis is Struktur

Struktur dari Amsal 10:2-3 mengikuti pola kiasmus/konsentris (dengan model: ABB'A'). ${ }^{35}$ Dimana Amsal ini membentuk empat-baris (quatrains) yang saling berhubungan antara ayat kedua dan ketiga. ${ }^{36}$ Bila memperhatikan ayat-ayat ini, maka akan memberikan pola seperti berikut,

${ }^{30}$ Roland E. Murphy, Word Biblical Commentary-Volume 22-Proverbs (Colombia: Thomas Nels on Publishers, 1998), 73. Penjelasan yang sama juga dijelaskan oleh Duane Garret mengenai arti kata נִּרִ "nefeš". Garrett, The New American Commentary, 117.

${ }^{31}$ Brown, S. R. Driver, dan Charles A. Briggs, A Hebrew And English Lexicon of the Old Testament, 659.

${ }^{32}$ Fox, Proverbs 10-31: A New Translation With Introduction And Commentary, 511.

${ }^{33}$ Dari kata benda הַוּה kata benda umum feminism tunggalkonstruk. Francis Brown, S. R. Driver, dan

Charles A. Briggs, A Hebrew And English Lexicon of the Old Testament, 217.

${ }^{34}$ Robert Alter, The Wisdom books: Job, Proverbs, and Ecclesiastes: a translation with commentary

(London: W. W Norton \& Company, 2010), 289.

${ }^{35}$ Roland Meynet, Rethorical Analysis: An Introduction to Biblical Rhetoric (Sheffield: Sheffield Academic Press, 1998), 233.

${ }^{36}$ Roland E. Murphy, The Wisdom Literature (Grand Rapids: Wm. B. Eerdmans Publishing Co, 1983), 68. 


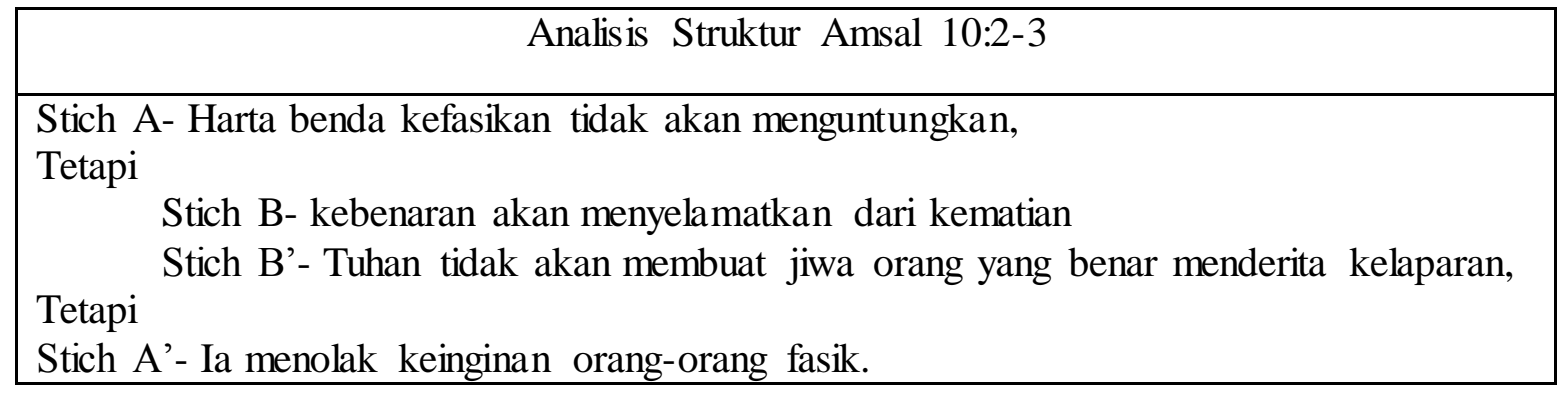

Stich A-A' dan B-B' merujuk kepada paralelisme antitesis, dimana stich A-A' berlawanan secara kontras dengan stich B-B'. Oleh sebab itu, antara stich A-A' dan B-B' memberikan kekontrasan antara cara orang fasik (kebohongan) dan cara orang yang benar (kejujuran). ${ }^{37}$ Bahkan, memberikan kekontrasan antara respon/peran Allah kepada cara-cara orang fasik dan orang benar. Keempat baris tersebut telah menunjukan susunan yang konsentris dari masing-masing ayat untuk memperjelas antara bagian kalimat-kalimat yang lain. ${ }^{38}$

Dari sisi yang lain, struktur dari kedua ayat ini dimulai dengan partikel negatif yaitu " לאי " "yang berarti "tidak." " Partikel tersebut memberikan keterangan-keterangan untuk menjelaskan fungsi dari setiap kata kerja pada stich A (Harta benda kefasikan tidak akan menguntungkan) dan B' (Tuhan tidak akan membuat jiwa orang yang benar menderita kelaparan), dimana pemaparan dari amsal-amsal ini merujuk kepada bahasa puisi yang dipakai dalam kepenulisan raja Salomo. ${ }^{40}$ Amsal 10:2-3 memberikan ciri khas kepenulisan terhadap berbagai pola, paralelisme dan struktur masing-masing kalimat dari amsal itu sendiri. Sehingga, para pembaca dan penafsir kitab dapat dimudahkan untuk memahami maksud dan tujuan dari kepenulisan amsal tersebut.

Kesimpulan Teks Amsal 10:2-3

Amsal 10:2-3 memberikan paparan secara kontras antara cara-cara orang fasik (berdasarkan pada kebohongan dan ketidakadilan) dan cara-cara orang benar melalui kejujuran/kebenaran. Dalam hal ini, kedua cara tersebut memberikan suatu dampak yang berpengaruh pada peran Allah sendiri. Kejujuran dalam pengelolaan harta akan menghasilkan pemeliharaan orang-orang benar dari suatu kesulitan, sedangkan kebohongan yang dilakukan oleh orang-orang fasik akan berdampak kepada kesia-siaan, bahkan suatu yang keji di hadapan Tuhan.

Kedua ayat ini memberikan sifat-sifat bijak (virtue) yang mengarahkan pilihan seseorang untuk bersikap atau berperilaku secara jujur. Tindakan ini didorong oleh Penulis Amsal, supaya para pembaca dapat menentukan setiap cara yang benar dan dapat mengetahui setiap konsekuensi terhadap tindakan-tindakan yang diambilnya. Dalam hal ini, Amsal 10:2-3

\footnotetext{
${ }^{37}$ Ibid.

${ }^{38}$ Meynet, Rethorical Analysis, 233.

${ }^{39}$ Kata $"$ "
} dengan arti ini bersama dengan aspek perfek dan imperfek. Carl A. Reed, Diktat Kuliah: Gramar dan Sintaks Bahasa Ibrani, sem. III, 2004.

${ }^{40}$ Murphy, The Wisdom Literature, 68. 
dapat melatih karakter seseorang untuk mengantisipasi setiap efek-efek yang buruk, sehingga ia dapat mengubah cara tindakannya agar orang tersebut menikmati konsekuensi yang benar/positif, yaitu: "tidak dibiarkannya orang benar menderita." Hal ini merupakan anugerah Allah bagi orang benar dan memelihara hidup orang tersebut dari kelaparan.

\section{Komentar Teks Amsal 10:4}

Pada pembentukan karakter selanjutnya, penulis akan membahas mengenai hal "ketekunan" sebagai salah satu aspek yang penting dalam pengumpulan harta. Dalam mengkaji tindakan ini, Amsal 10:4 menjadi teks yang penting untuk menjelaskan hal-hal yang berkaitan dengan "ketekunan." Oleh sebab itu, ada beberapa analisis yang akan dijelaskan oleh penulis seperti berikut.

Analis is Terjemahan dan Catatan Teks

\begin{tabular}{|c|c|}
\hline Teks Ibrani & Terjemahan Teks \\
\hline 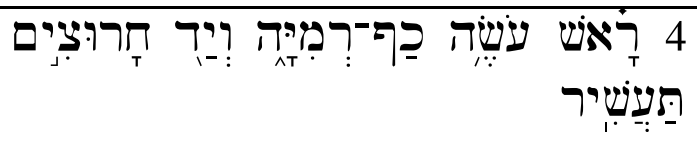 & $\begin{array}{l}\text { 4. Tangan yang lamban menyebabkan } \\
\text { kemiskinan, tetapi tangan yang rajin akan } \\
\text { menjadikan kaya. }\end{array}$ \\
\hline
\end{tabular}

Pada pemaparan ini, penulis akan memberikan 4 (empat) catatan teks yang penting dalam terhadap terjemahan Amsal 10:4. Pertama, kata רִ רִּ " "kelambanan, kebohongan ataupun penipuan." 41 Walaupun banyak terjemahan dari kata ini,

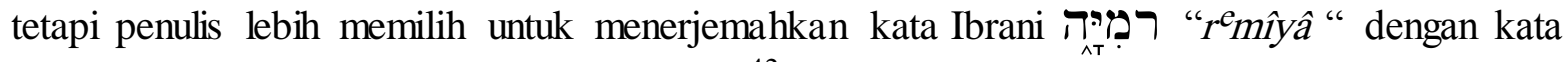
"lamban" yang sesuai dengan arti kamusnya. ${ }^{42}$ Perlu diingat bahwa frase "Tangan yang lamban" merupakan salah satu tema besar dalam kitab Amsal. Tema ini juga didapatkan dalam pasal 12:11, 24, 27;18:9, sehingga frase ini cukup banyak ditulis oleh Raja Salomo. ${ }^{43}$ Hal inilah yang menjadi alasan bagi penulis untuk menerjemahkan kata "lamban" sebagai terjemahan dari ayat 4. Selain diterjemahkan sebagai "lamban," makna dari kata ini tidak dapat dipisahkan dari sifat seseorang untuk melakukan "kebohongan atau pengabaian."44 Oleh karena itu, Frase "tangan yang lamban" memiliki arti sebagai sikap seseorang yang lamban (malas), bahkan mempunyai sikap untuk berbohong dan sembrono dalam melakukan pekerjaan tertentu.

${ }^{41}$ TWOT Lexicon, Bibleworks 9. Copyright (C) 2011 bibleworks, LLC Version 9.0.

${ }^{42}$ kata רפירזיה " $r^{e}$ mîyâ" memiliki ide yang dasarbahwa seseorang dapat membawa dirinya sendiri jatuh kepada sifat kemalasan dan sulit untuk mengendalikan dirinya, sehingga dapat memberikan dampak yang begitu fatal. Keil, F. Delitzsch, Biblical Commentary On The Old Testament, (Grand Rapids: Eerdmans Publishing, 1950), 210.

${ }^{43}$ Sinulingga, Tafsiran Alkitab: Amsal 10:1-22:16, 38.

${ }^{44}$ Holladay, A Concise Hebrew And Aramic Lexicon of the Old Testament, 340. Michael Fox

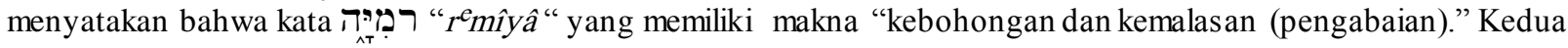
makna diatas merupakan hubungan dari sistem-penilaian Amsal, karena orang-orang bijak memiliki kecenderungan untuk menyatukan pengetahuannya terhadap prinsip-prinsip moral dari makna tersebut . Gagasan dari ayat ini juga terdapat pada Amsal 12:24;19:15 dan 12:24, 27. Lihat, Fox, Proverbs 10-31: A New Translation With Introduction And Commentary, 512. 


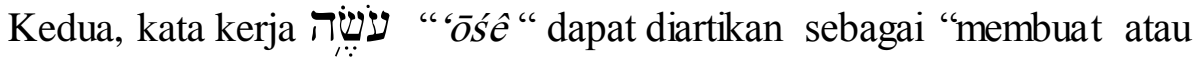
menyebabkan."45 Pada terjemahan ini, penulis memilih untuk menerjemahkan kata kerja diatas dengan kata "menyebabkan." Ada 2 (dua) alasan yang mendasar bagi penulis untuk

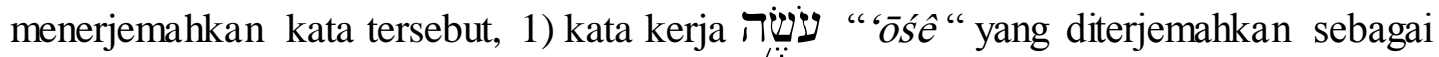
"menyebabkan" memiliki unsur sebab-akibat antara "tangan yang lamban" dan "kemiskinan."

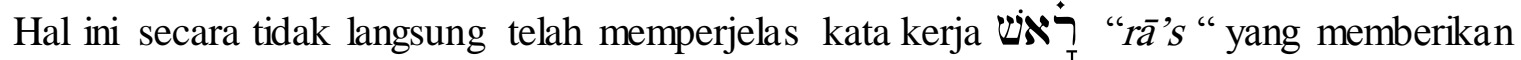
dampak dari kelambanan dan kemalasan, sehingga seseorang akan "menjadi miskin."46 2) jika

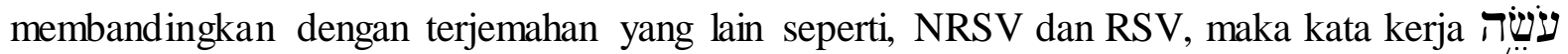
" 'ôśê " juga dapat diartikan sebagai kata "menyebabkan." Dalam ayat 4a, "Tangan yang lamban menyebabkan kemiskinan," dapat mengungkapkan kerawanan seseorang dalam bekerja, yang mana banyak perkara (kelambanan, kemalasan ataupun kebohongan) mengakibatkan dirinya menjadi miskin.

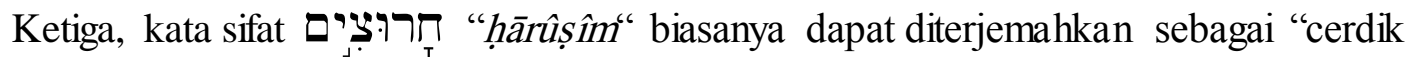
atau rajin."47 Kata sifat ini digunakan sebagai cara/tindakan seseorang untuk menghindari dari kemiskinan, bahkan kemampuannya dapat memberikan rasa cukup pada saat memperoleh kekayaan. ${ }^{48}$ Sifat dari karakter ini dapat menunjukkan bahwa ketekunan dan kerja keras dapat dilakukan dari setiap pekerjaan. Keempat, kata kerja "tâ’āshîr" diartikan sebagai "menjadikan kaya."49 Kata kerja ini memberikan suatu konsekuensi dari seseorang yang melakukan pekerjaannya dengan tekun. Konsekuensi ini tentunya didasarkan pada proses, sehingga dari sifat ketekunan yang dilakukan oleh orang tersebut akan memperoleh kekayaan.

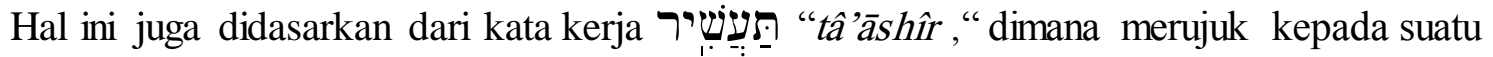
tindakan yang akan memperoleh hasil pada saat mendatang. Oleh sebab itu, sikap rajin dari seseorang akan menghasilkan suatu kemampuan yang dilakukan secara terus-menerus, sehingga dalam prosesnya orang tersebut akan menghasilkan kekayaan.

\section{Analis is Struktur}

Struktur dari Amsal 10:4 mengikuti pola dua-baris (bicolon), yang adalah bentuk dasar dari subgenre Amsal atau mashal. Amsal ini membentuk dua baris yang saling berhubungan antara Stich A dan Stich B. ${ }^{50}$ Menurut Roland E. Murphy, Amsal 10:4 membentuk model/tipe frase: $a-a$ '-b-b'. ${ }^{51}$ Kiasme ini terdapat pada tingkatan kalimat dari pasal 10:4. Hal tersebut dapat diperhatikan pada tabel di bawah ini.

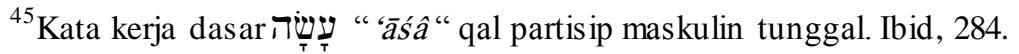

${ }^{46}$ Kata kerja dasarשיש "rîs " qal partisip maskulin tunggal. Istilah lain dari kata miskin dapat diperhatikan dari kata "'ebyôn" dan ānî. Owens, Analytical Keyto the Old Testament, 546. Lih. Brown, Hebrew and Lexicon with an Appendix Containing the Biblical Aramic, 910, 930.

${ }^{47}$ Dari kata sifat "ḥarụ̂ṣ" maskulin jamak. Brown, Hebrew and Lexicon with an Appendix Containing the Biblical Aramic, 358.

${ }^{48}$ Whybray, Wealth And Proverty In The Book of Proverbs, 15.

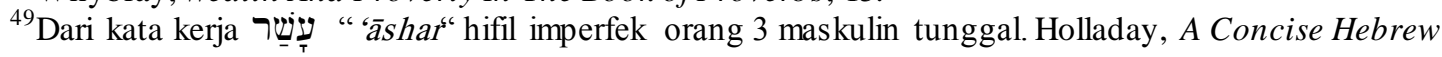
And Aramic Lexicon of the Old Testament, 286.

${ }^{50}$ Meynet, Rethorical Analysis, 231.

${ }^{51}$ Murphy, The Wisdom Literature, 68.
} 


\begin{tabular}{|c|c|}
\hline \multicolumn{2}{|c|}{ Analis is Struktur Amsal 10:4 } \\
\hline $\begin{array}{l}\text { Stich A- Tangan yang lamban } \\
\text { menyebabkan kemiskinan }\end{array}$ & $\begin{array}{l}\text { (frase a) } \\
\text { (frase a') }\end{array}$ \\
\hline $\begin{array}{l}\text { Stich B- Tangan yang rajin } \\
\text { akan menjadikan kava }\end{array}$ & $\begin{array}{l}\text { (frase b) } \\
\text { (frase b') }\end{array}$ \\
\hline
\end{tabular}

Amsal 10:4 memberikan paralelisme yang berbentuk antitesis, dimana stich A merupakan kalimat yang berlawanan secara kontras dengan kalimat yang ada pada stich $\mathrm{B} .{ }^{52} \mathrm{Hal}$ ini dapat diperhatikan kekontrasan antara (frase a) tangan yang lamban dan (frase b) tangan yang rajin. Antitesis pada frase a dan b dapat memberikan suatu perbedaan antara sifat/karakter seseorang yang didasarkan pada sifat kemalasan, kebohongan ataupun pengabaian dalam melakukan pekerjaan, dan sifat dari karakter seseorang yang tekun, serta ulet dalam mengerjakan tanggungjawabnya. Sedangkan pada frase a' dan b' merupakan antitesis antara orang yang memperoleh kemiskinan dan kekayaan.

Sisi yang lain, Amsal 10:4 memakai tipe/pola perkataan karakter-konsekuensi. ${ }^{53}$ Dimana frase a'-b' merupakan konsekuensi/dampak dari karakter seseorang yang lamban dan tekun. Jika memperhatikan dalam frase a', maka orang yang lamban (frase a) dalam pekerjaan akan mengakibatkan pada kemiskinan. Sedangkan pada frase b', seseorang yang mempunyai sifat karakter rajin dalam bekerja akan menghasilkan kekayaan. Hal tersebut merupakan konsekuensi yang akan diterima bagi orang yang rajin. Tabel di bawah ini akan memperjelas maksud dari tipe perkataan karakter-konsekuensi.

\begin{tabular}{|c|c|c|c|c|}
\hline \multicolumn{5}{|c|}{ Tipe perkataan karakter-konsekuensi Amsal 10:4 } \\
\hline Stich & Frase & Karakter & Frase & Konsekuensi \\
\hline A & a & Tangan yang lamban & a' & menyebabkan kemiskinan \\
\hline B & b & Tangan yang rajin & b' & akan menjadikan kaya \\
\hline
\end{tabular}

Analisis struktur dari Amsal 10:4 telah memberikan ciri khas kepenulisannya, terlebih gaya puisi dan struktur yang membuat pesan dari amsal ini lebih dimengerti oleh para pembaca. Melalui analisis ini, selain menekankan perbedaan secara kontras antara orang yang lamban dan rajin berserta dengan konsekuensinya masing-masing, penulis Amsal juga memberikan penekanan kepada pembaca untuk dapat memilih sifat dari karakter seseorang dalam mengumpulkan harta yang benar. Walaupun, Amsal 10:4 dapat menyampaikan makna dari pengalaman-pengalaman yang terjadi, tetapi pemilihan sifat bijak dari sisi ketekunan memberikan pengajaran-pengajaran moral bagi pembaca amsal.

Kesimpulan Teks Amsal 10:4

Amsal 10:4 telah memberikan sifat yang bijak dalam pengumpulan harta yang benar. Salah satu yang dapat dipelajari pada bagian ini adalah ketekunan. Penulis Amsal sangat memuji

\footnotetext{
${ }^{52}$ Murphy, Word Biblical Commentary-Volume 22 - Proverbs, 73.

${ }^{53}$ Sandy, Ronald L. Giese, Jr, Cracking Old Testament Codes, 236.
} 
seseorang yang tekun dalam melakukan suatu pekerjaan, dibandingkan dengan orang yang malas atau lamban.

Pada bagian ini, sifat tekun merupakan salah satu sifat bijak (virtue) yang ditekankan oleh penulis Amsal. Sifat ketekunan adalah suatu kebiasaan yang menghasilkan karakter yang baik, sehingga membentuk suatu sikap rajin bagi diri seseorang sebagai suatu perbuatan yang dilakukan secara terus-menerus. Oleh sebab itu, ayat ini membentuk suatu sikap/tindakan rajin seseorang, sehingga ia dapat mengumpulkan (sebagai efek/konsekuensi) kekayaannya.

\section{Komentar Teks Amsal 10:5}

Dalam Penafsiran Amsal 10:5, memang ada perbedaan antara pendapat para ahli kitab Amsal mengenai keterkaitan struktur/paralelismenya. Menurut Roland E. Murphy, ayat 5 merupakan suatu kesejajaran/paralelisme dengan ayat 4. Hal ini dibuktikan dengan kesamaan penekanan topik antara seorang yang rajin dan malas. ${ }^{54}$ Dari sudut pandang yang lain, Duane A. Garret menganggap bahwa ayat 5 merupakan Amsal yang berdiri sendiri. Ia beranggapan bahwa ayat 5 berbicara khusus tentang kehidupan pertanian yang tentunya berbeda dengan ayat $4 .{ }^{55}$ Sedangkan, Michael V. Fox beranggapan bahwa ayat 5 memiliki kesejajaran dengan ayat 1 karena memiliki suatu pengulangan (repetition) tentang karakter Anak. Karakter dari seorang anak pada ayat kelima juga memberikan suatu konsekuensi/efek kepada orang tua. ${ }^{56}$ Oleh sebab itu, penulis akan mengkaji Amsal 10:5 untuk menemukan hasil tafsiran terhadap pentingnya pembentukan karakter terhadap anak dan memberikan posisi yang tepat kepada hubungan paralelisme/struktur tentang "peran orang tua kepada Anak" dalam Amsal 10:1-5.

Analis is Terjemahan dan Catatan Teks

\begin{tabular}{|c|c|}
\hline Teks Ibrani & Terjemahan Teks \\
\hline 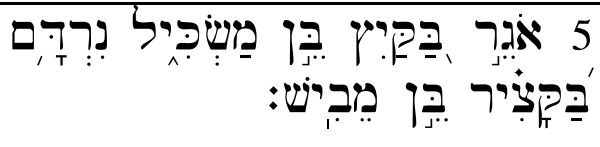 & $\begin{array}{l}\text { 5. Siapa mengumpulkan pada musim panas, } \\
\text { anak yang berakal budi tetapi siapa tidur } \\
\text { pada waktu panen, anak }{ }^{57} \text { yang memalukan. }\end{array}$ \\
\hline
\end{tabular}

Dalam proses terjemahan ayat 5, penulis mempunyai 2 (dua) catatan teks yang patut

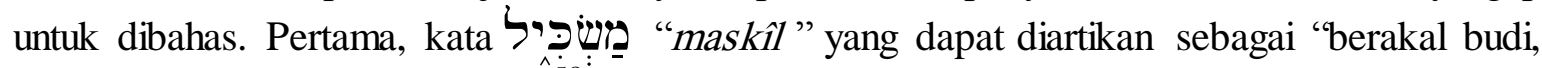
menjadi cerdik, sukses/berhasil. ${ }^{, 58}$ Penulis memilih untuk menerjemahkan kata ini yaitu

${ }^{54}$ Roland E. Murphy, Word Biblical Commentary-Volume 22-Proverbs, 73. Roland E. Murphy, The Wisdom Literature, 68.

${ }_{55}^{5}$ Duane A. Garrett, The New American Commentary, 91.

${ }^{56}$ Fox, Proverbs 10-31: A New Translation With Introduction And Commentary, 513.

${ }^{57}$ Pada ayat 5a dan 5b dicatumkan kata Ibrani bēnyang artinya "seorang anak." Lembaga Alkitab Indonesia (LAI) tidak memakai kata "Anak" dalam ayat ini (LAI, ayat 5: "Siapa mengumpulkan pada musim panas, ia berakal budi; siapa tidur pada waktu panen membuat malu").

${ }^{58}$ Dari tujuh puluh empat kali kata kerja dari digunakan, semua kecuali dua kali muncul sebagaikata kerja Hifil. Dalam banyak contoh kata ākal identik/sinonim dengan kata ḥokmâ yang artinya hikmat atau menjadi bijak.. kata ākal sendiri berhubungan dengan pengetahuan yang cerdas tentang alasannya. Ada proses berpikir melalui pengaturan pemikiran yang rumit yang menghasilkan transaksiyang bijaksana dan penggunaan akal sehat 
"berakal budi." Selain bentuk kata kerjanya (Hifil partisip maskulin tunggal), alasan pemilihan kata kerja "berakal budi" memberikan terjemahan tepat karena konteks sebelumnya pada ayat 1 berbicara mengenai sifat "anak yang bijak" yang juga ditekankan pada ayat 5 (mengingat bahwa kata $\boldsymbol{T}_{\mathrm{T}}$ " "hākām" yaitu hikmat dan "maskîl” yaitu akal budi merupakan kata kerja yang bersinonim). Ayat 5a memberikan suatu penjelasan bahwa orang yang berakal budi akan menunjukan sifat rajin dan tekun. Hal ini diperjelas dengan kalimat "siapa yang mengumpulkan pada musim panas" dalam situasi/masa yang tepat untuk mengumpulkan hasil panen (dalam konteks pertanian), sehingga anak tersebut dapat menyimpan suatu persediaan cukup dalam waktu yang panjang. Oleh sebab itu, seorang "anak yang berakal budi" akan menunjukan pikiran dan rancangan yang benar, bahkan juga memiliki intelektualitas yang tajam untuk masa yang akan datang.

Memang secara tidak langsung ayat ini mempunyai hubungan konteks dengan ayat 4 dimana harta benda atau kekayaan harus diperoleh dengan kerja keras, kerajinan ataupun ketekunan. Namun dibalik penekanan pada ayat 5a, Salomo memperjelas bahwa kerajinan sangat identik dengan seorang anak yang berakal budi.

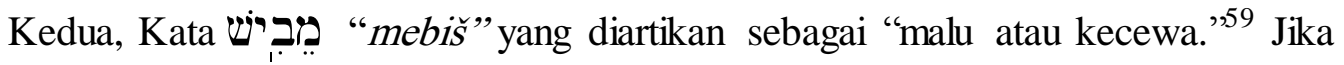
memperhatikan konteks di dalam kitab Amsal, maka kata kerja ini biasanya menjelaskan tentang konsekuensi atau respon dari tindakan bebal ("siapa tidur di waktu panen" merujuk kepada tindakan seorang pemalas) seseorang yang menyebabkan orang lain malu terhadap tindakannya tersebut, khususnya kepada derajat orang yang dianggap lebih tinggi atau dihormati, contohnya: seorang anak kepada orangtuanya (Ams. 19:26; 29:15), seorang istri kepada suami (Ams. 12:4), dan seorang hamba kepada raja (14:35). Biasanya dalam kitab Amsal, kata kerja ini menjelaskan tentang sifat kepribadian seseorang (Band. Ams. 10:5; 12:4; 14:35; 17:2; 19:26 dan 29:15). ${ }^{60}$ Oleh sebab itu, penulis menerjemahkan kata kerja ini sebagai "anak yang memalukan" untuk menunjukan bahwa tindakan yang bebal akan memiliki respon atau tanggapan yang tidak baik bagi orang sekelilingnya, seperti: orangtuanya (ay. 1) ataupun lingkungan masyarakat.

Ajaran mengenai seorang anak yang rajin dan kaya serta seorang anak malas dan miskin yang dikemukakan dalam ayat ini tidaklah berlaku secara mutlak. Adakalanya Penulis Amsal menyadari bahwa si pemalas dan penipu dapat menjadi kaya walaupun hanya untuk sementara, tetapi seorang yang rajin tidak berhasil menjadi kaya. ${ }^{61}$ Konteks dari keseluruhan kitab Amsal juga ditemukan dalam Amsal 12:24, 27; 19:15; 21:5, dimana maksud kekayaan bukan dalam arti "kekayaan yang melimpah" seperti kehidupan modern, namun konteks kehidupan yang dimaksud dalam ayat 5 adalah kehidupan masyakarat petani yang sederhana dan mempunyai sifat ketekunan tersebut.

Analis is Struktur

praktis yang baik. Hasil akhir lainnya adalah penekanan pada menjadi sukses. R. Laird Harris, Gleason L. Archer, Jr., Bruce K. Waltke, Theological Wordbook of the Old Testament, 421.

59 Ibid, 36.

${ }^{60}$ Fox, Proverbs 10-31: A New Translation With Introduction And Commentary, 514.

${ }^{61}$ Whybray, Wealth And Proverty In The Book of Proverbs, 60-74. 
Menurut penulis ada 2 hal analisis struktur yang patut dikaji dalam Amsal 10:5. Pertama, Amsal 10:5 memiliki struktur yang yang bersifat pengulangan/repetisi. ${ }^{62}$ Pengulangan kata dan pola bunyi sangat memperkuat antitesis yang tajam dalam Amsal ini.

\begin{tabular}{|c|c|c|}
\hline & $\begin{array}{l}\text { 'ōgēr baqqayiṣ bēn maśkîl } \\
\text { berakal budi }\end{array}$ & Siapa mengumpulkan pada musim panas, anak yang \\
\hline$b$. & $\begin{array}{l}\text { nirdām baqqāṣ̂î bēn mēbîš } \\
\text { memalukan }\end{array}$ & : tetapi siapa tidur pada waktu panen, anak yang \\
\hline
\end{tabular}

Pemaparan dari tabel di atas patut untuk diperhatikan, karena ada beberapa pengulangan/repitisi yang terjadi pada Amsal ini, seperti kata bēn dimana memberikan tempat yang penting pada kedua baris (masing-masing di bagian akhir kalimat) dengan diikuti kata sifat yang sangat kontras. ${ }^{63}$ Sebenarnya, hal yang bersifat kontras dan sinonim memainkan peranan penting dalam struktur Amsal 10:5. Dalam setiap kasus, kesejajaran (paralelisme) pada tingkat semantik ${ }^{64}$ memiliki suatu sifat yang kontras atau sinonim; tetapi dalam setiap kasus, amsal ini juga bergema (pengulangan) pada tingkat suara. Tabel di bawah ini memberikan penjelasan terhadap repitisi Amsal 10:5.

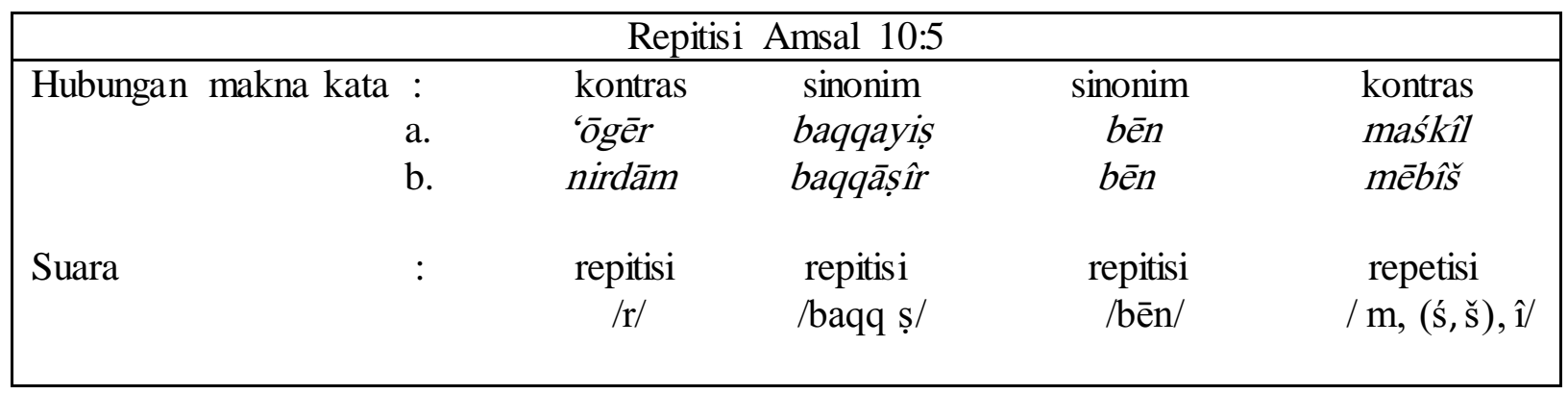

Dengan demikian, paralelisme gramatikal, paralelisme terhadap makna kata antara dua istilah di bagian tengah dari masing-masing baris kalimat yaitu kata baqqayị̣ = baqqāṣ̂r dan bēn merupakan kata-kata repitisi, dan juga pola suara yang sama, dimana membentuk kesamaan latar belakang yang berfungsi untuk menekankan perbedaan terhadap makna kata dari dua istilah yang lain (yaitu 'ōgēr dan nirdām, serta maśkîl dan mēbîš) pada masing-masing baris kalimat. Oleh sebab itu, Amsal 10:5 menekankan pada situasi/masa yang sama yaitu musim panas/panen. Dimana, seorang petani pada masa tersebut dapat mengambil hasil panennya, namun Amsal 10:5

${ }^{62}$ Repetisi adalah susunan kata-kata atau elemen-elemen lain yang sama, yang mencakup motif, konsep, orang, bentuk-bentuk sastra ataupun hubungan-hubungan strukturyang lain. Meyer H. Abrams, A Glossary of Literary Terms, edisi ke 4 (New York: Holt, Rinehart\&Winston, 1981),111; David R. Bauer, Robert A. Traina, Inductive Bible Study: Langkah-langkah Praktis memahami Hermeneutik Alkitab (Yogyakarta:ANDI, 2017), 120121.

63 Thomas P. McCreesh, Biblical Sound and Sense: Poetic sound patterns in Proverbs 10-29 (Sheffield: Journal for the Study of the Old Testamen, 1991), 126.

${ }^{64}$ Semantik bercirikan kemajuan ganda atau dua kali lipat yang digunakan untuk mengindikasikan hubungan dalam hal arti: pergerakan dari sesuatu ke sesuatu. (contohnya:kontras, perbandingan, klimaks, partikularisasi, Generalisasi, sebab-akibat, pembenaran dan Krusialitas). David R. Bauer, Robert A. Traina, Inductive Bible Study: Langkah-langkah Praktis memahami Hermeneutik Alkitab, 122-147. 
menunjukan suatu sifat tindakan yang kontras, ada seorang yang rajin, namun ada seorang anak yang tidur, sehingga di bagian penutup baris, penulis Amsal memberikan kesimpulan yang berbeda. Seorang anak yang rajin adalah seorang yang berhikmat, sedangkan seorang anak yang malas adalah seorang yang memalukan.

Kedua, Amsal 10:5 secara mendalam mengikuti pola dua baris (distich), dimana Stich A dan Stich B membentuk paralelisme secara antitesis (kontras). Dari sudut pandang yang lain, Amsal ini membentuk model atau tipe: $a-a$ '-b-b' ${ }^{65}$ Tabel di bawah ini memperjelas maksud model empat baris: $a-a '-b-b$ '.

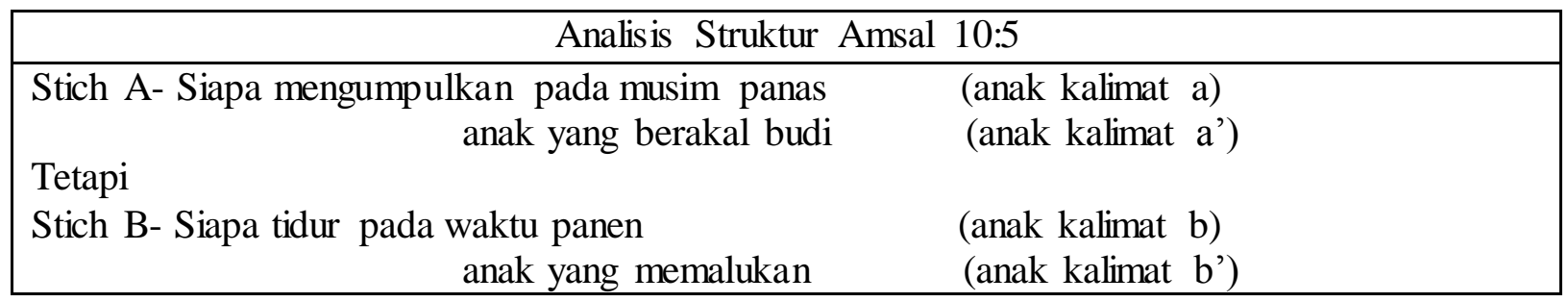

Jika memperhatikan analisa Struktur dalam Amsal 10:5, maka dapat ditemukan 2 bagian yang menunjukan antitesis dari bagian ini. Pertama, antitesis antara anak kalimat a "siapa mengumpulkan pada musim panas" dan anak kalimat b "siapa tidur pada waktu panen. Kedua anak kalimat tersebut menunjukan suatu tindakan yang kontras antara seorang anak mengumpulkan hasil panen pada hari panas dengan seorang yang hanya berbaring tidur pada waktu panen. Nampaknya, penulis Amsal ingin menunjukan suatu pekerjaan yang sama yaitu Petani, musim yang sama yaitu musim panas atau musim panen, namun dengan sifat tindakan yang berbeda (Sifat rajin dan malas). ${ }^{66}$ Kedua, antitesis antara anak kalimat a' "anak yang berakal budi “ dan anak kalimat b' "anak yang memalukan” merupakan antitesis yang menunjukan hasil dari tindakan anak kalimat a ("siapa mengumpulkan pada musim panas") dan b (siapa tidur pada waktu panen"). Oleh sebab itu, hasil dari kedua tindakan yang berbeda tersebut akan memberikan suatu evaluasi, hasil atau penilaian dari orang sekitar, termasuk di dalamnya adalah keluarga ataupun penilaian masyarakat.

Dengan memperhatikan pernyataan penutup dari paragraf di atas, maka penulis mengambil suatu kesimpulan bahwa Amsal 10:5 memakai pola perkataan dengan model Tindakan-Evaluasi. Tabel di bawah ini akan memberikan maksud/pengertian dari penulis tentang model tindakan-Evaluasi.

\begin{tabular}{|c|c|c|c|c|}
\hline \multicolumn{5}{|c|}{ model perkataan Tindakan-Evaluasi Amsal 10:5 } \\
\hline Stich & $\begin{array}{c}\text { Anak } \\
\text { Kalimat }\end{array}$ & Tindakan & $\begin{array}{c}\text { Anak } \\
\text { Kalimat }\end{array}$ & Evaluasi \\
\hline A & a & $\begin{array}{c}\text { Siapa mengumpulkan pada } \\
\text { musim panas }\end{array}$ & a' & anak yang berakal budi \\
\hline B & b & Siapa tidur pada waktu panen & b' & anak yang memalukan \\
\hline
\end{tabular}

\footnotetext{
${ }^{65}$ Meynet, Rethorical Analysis, 232.

${ }^{66}$ John W. Miller, Believers Church Bible Commentary: Proverbs (Pennsylvania: Herald Press, 2004),
}

174-175. 
Tindakan seseorang yang mengumpulkan hasil panen pada musim panas dinilai atau dievaluasi sebagai seorang anak yang berakal budi. Sebaliknya, seorang yang tidur pada waktu menuai dinilai sebagai anak yang memalukan. Penulis Amsal sebenarya mengajarkan kepada pembacanya untuk memiliki suatu tindakan yang rajin dalam melakukan tugas dan tanggung jawabnya, sehingga penilaian/tanggapan dari orang-orang sekitar akan berdampak baik atas kehidupannya, baik dalam hubungan komunitas kecil yaitu keluarga dan komunitas besar yaitu lingkungan masyarakat.

\section{Kesimpulan Teks Amsal 10:5}

Amsal 10:5 sangat menekankan kepada sifat bijak (virtue) kepada seorang anak. Sifat bijak yang ditekankan di sini adalah sifat ketekunan/kerajinan. Penulis Amsal memberikan suatu antitesis dengan seorang yang malas untuk melakukan suatu pekerjaan. Akhir dari masingmasing kalimat memberikan suatu evaluasi atau penilaian yang tajam. Seorang anak yang rajin dinilai sebagai seorang anak yang berakal budi, sedangkan seorang yang malas dinilai sebagai seorang anak yang memalukan. Penilaian/evaluasi atas tindakan seseorang dapat berasal dari komunitas keluarga sampai kepada komunitas masyarakat.

\section{Pertalian Struktur Amsal 10:1-5}

Jika memperhatikan setiap analisis dalam Amsal 10:1-5, maka Amsal 10: 1 secara literal menghubungkan dirinya dengan Amsal 10: 5 melalui pengulangan ganda dari kata '"anak + Kualitas karakter" (10: 1, bijak / bodoh; 10: 5, bijaksana / memalukan) yang memiliki suatu pertalian struktur (string). ${ }^{67}$ Amsal 10:1 sendiri memang dipisahkan dari tema kekayaan yang dijelaskan secara tersendiri dalam Amsal 10: 2-5. Namun begitu, Amsal 10: 1 tampaknya memberikan transisi/engsel yang menghubungkan kembali kepada tema utama yaitu "seorang anak yang bijaksana" pada Amsal 1-9 sambil memberikan judul untuk kalimat amsal yang akan mendominasi dalam Amsal 10: 1-22: $16 .{ }^{68}$ Oleh sebab itu, penulis ingin menunjukan bahwa Amsal 10:1-5 memberikan pertalian struktur yang saling mengikat, meskipun ada beberapa penjelasan dalam Analisa struktur pada Amsal 10:2-3 yang sudah dijelaskan oleh penulis sebelumnya.

Dalam hal ini penulis akan menjelaskan 2 pertalian struktur dalam Amsal 10:1-5. Pertama, pertalian struktur dalam Amsal 10:2-3. Amsal ini membentuk pasangan yang berpusat pada tema tentang hubungan orang fasik/benar dengan kekayaan/kemiskinan. Kata kerja lo + kata kerja Hifil Imperfek, secara sintaksis mengikat kedua ayat tersebut secara bersamaan. Secara leksikal, Amsal 10: 2 dan 3 juga membentuk suatu kiasme yang berasal dari akar kata "kebenaran" / "orang yang benar" dan "jahat"/ "orang fasik." ${ }^{69}$

${ }^{67}$ Ted Hildebrandt, "Proverbial Strings: Cohesion in Proverbs 10," Grace Theological Journal 11.2

(1990), 173.

${ }^{68}$ Murphy, The Wisdom Literature, 68.

${ }^{69}$ Akar kata memiliki variasi secara morfologis dalam genderkata ("kebenaran," feminim./"orang orang yang benar, "maskulin") Dan jumlah (" Fasik, " tunggal/jamak). 


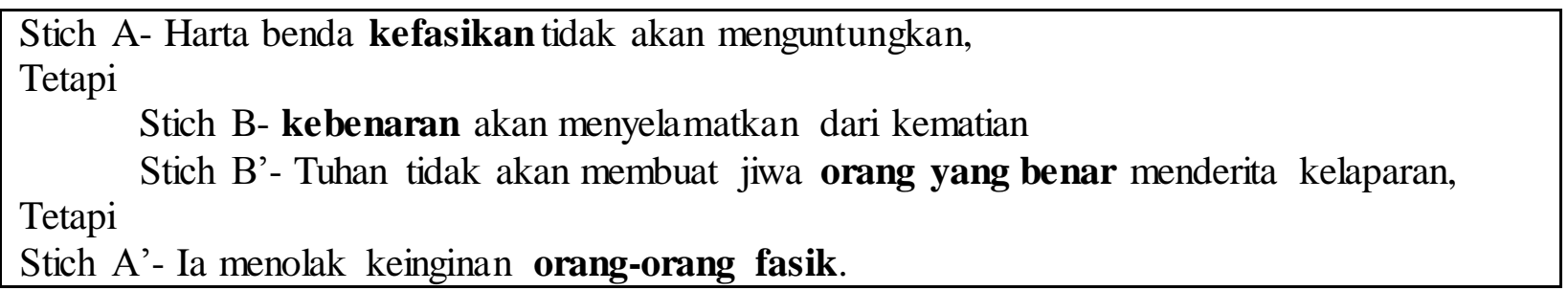

Pertalian struktur kedua, Amsal 10: 4-5 yang melanjutkan tema tentang kekayaan/kemiskinan yang berfokus pada hubungannya dengan ketekunan/kemalasan. Sekali lagi, ada kata-kata kiasme dalam suatu ikatan yang secara semantik dapat dipicu. Tabel di bawah ini memperjelas maksud dari kiasme Amsal 10:4-5.

\begin{tabular}{|l|}
\hline \multicolumn{1}{|c|}{ Kata-kata Kiasme Amsal 10:4-5 } \\
\hline A- Tangan yang lamban-kemiskinan \\
Tetapi \\
\multicolumn{1}{|c|}{ B- rajin-menjadikan kaya. } \\
B'- Siapa mengumpulkan-anak yang berakal budi \\
Tetapi \\
A'- siapa tidur-anak yang memalukan \\
\hline
\end{tabular}

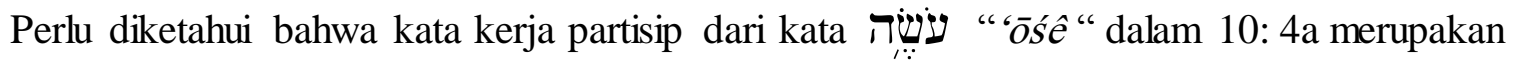
lingkaran nada yang sama dengan kata kerja אגיר 'ögèr pada Amsal 10: $5 a{ }^{70}$ Sebenarnya secara tematik (ketekunan/kemalasan), kedua amsal di atas saling berhubungan meskipun tidak ada keterkaitan antar akar kata satu dengan yang lainnya. Kurangnya hubungan leksikal dalam kedua pasangan amsal ini mendorong penulis untuk menemukan hal lain yang terselubung dari pengulangan ganda terhadap frase yang berfokus berbicara tentang tema karakter anak (" anak" + "karakter) antara ayat $1 \mathrm{a}$ dan ayat $5 \mathrm{a}$ serta ayat $1 \mathrm{~b}$ dan $5 \mathrm{~b}$, seperti yang dijelaskan oleh penulis dalam paragraf pertama tentang pertalian struktur Amsal 10:1-5. Tabel di bawah ini akan membuktikan pertalian struktur dalam Amsal 10:1-5.

\footnotetext{
${ }^{70}$ Merupakan repitisi pada kitab Amsal yang berdasarkan pada pengulangan konsonan/ vokal yang serupa atau identik dari satu kata ke kata lain dalam banyak pola-pola yang berbeda. McCreesh, Biblical Sound and Sense, 126.
} 


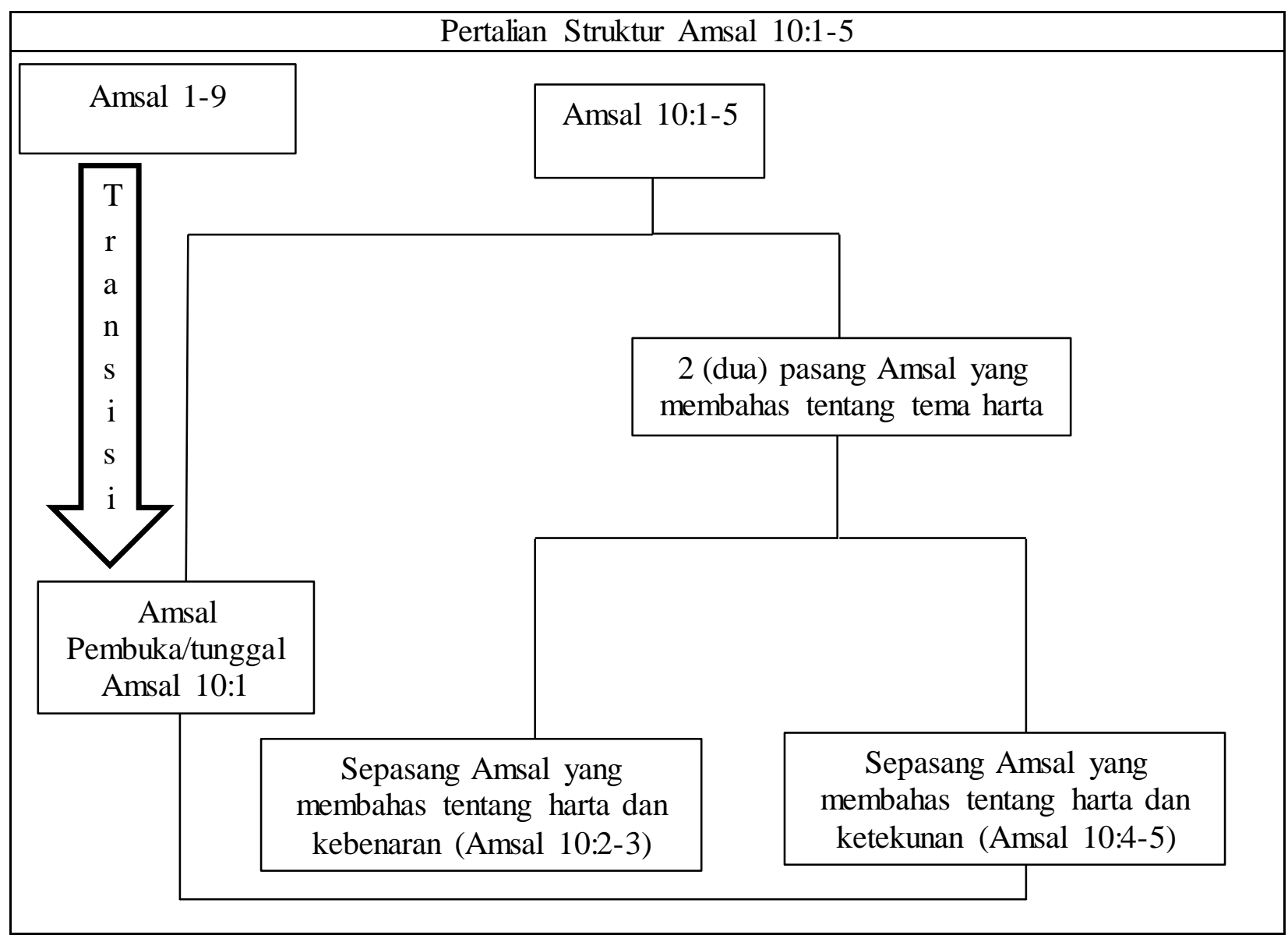

Hal ini juga dapat diperjelas dalam terjemahan Amsal 10:1-5 yang telah diterjemahkan oleh penulis sebelumnya, dimana memiliki hubungan/perpaduan secara erat dalam keterkaitan kata dan maknanya.

Terjemahan Amsal 10:1-5

1. Anak-anak yang bijak membuat seorang ayah bersukacita, tetapi anak yang bebal mendukakan ibunya.

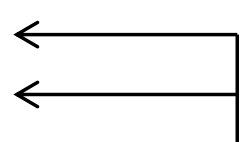

Sepasang Amsal yang membahas tentang harta dan kebenaran

2. Harta benda kefasikan tidak akan menguntungkan, tetapi kebenaran akan menyelamatkan dari kematian

3. Tuhan tidak akan membuat jiwa orang yang benar menderita kelaparan, Tetapi Ia menolak keinginan orang-orang fasik.

Sepasang Amsal yang membahas tentang harta dan ketekunan

4. Tangan yang lamban menyebabkan kemiskinan, tetapi tangan yang rajin akan menjadikan kaya.

5. Siapa mengumpulkan pada musim panas, anak yang berakal budi 
tetapi siapa tidur pada waktu panen, anak yang memalukan.

Dapat diringkas bahwa, Amsal 10: 1-5 terdiri dari dua pasangan struktur yang berpusat dari hubungan berbagai kualitas karakter (fasik/jujur [10: 2-3]; malas/rajin [10: 4-5]) kepada tema utama tentang kekayaan ataupun tentang kemiskinan. Sedangkan, ayat 1 dan ayat 5 merupakan pengulangan yang menjelaskan tentang seorang "anak" + frase kata benda terhadap sifat bijak dan bebal (10: la / b, 5a / b) dimana terlingk up pada bagian awal dan akhir dari Amsal 10:1-5. Kualitas bijak seorang anak memang memberikan suatu kebahagiaan dari orangtua (Amsal 10:1). Namun begitu, Amsal 10:1 merupakan transisi dari bagian Amsal 1-9 yang mana memberikan penjelasan bahwa kualitas karakter anak juga berasal dari peran didikan dari orangtua, mengingat ajaran-ajaran dari pasal 4 mengenai pentingnya nasihat dari mereka.

\section{Penutup}

Penulis telah menjelaskan analisa-analisa teks dan memaparkan pertalian struktur dalam Amsal 10:1-5. Dalam pembahasan ini, memang Amsal 10:1-5 tidak lepas dari konteks umum dari ajaran-ajaran dasar hikmat dalam Amsal 1-9. Sesuai dengan judul dari artikel ini yaitu "Studi análisis mengenai pertalian struktur Amsal 10:1-5 dan peran orang tua dalam pembentukan karaker," maka penulis menemukan beberapa kesimpulan melalui analisa ini. Pertama, pembentukan karakter seorang anak selalu diawali dari peran orangtua dalam memberikan proses pendidikan. Kunci terhadap pertalian Struktur Amsal 10:1-5 yang memberikan transisi/engsel dalam dasar-dasar hikmat Amsal 1-9, memberikan arah kepada penulis bahwa hasil dari kualitas anak yang berhikmat tidak lepas dari pendidikan dari orangtua. Hal ini perlu diketahui dimana proses pendidikan dalam keluarga juga terus-menerus berlaku di tengah-tengah kehidupan bangsa Israel, walau pada masa kerajaan, terutama di zaman pembuangan sendiri.

Kedua, peran orangtua dalam pendidikan nampaknya dilakukan secara seimbang yaitu ayah dan ibu. Amsal 10:1 menjelaskan bahwa kualitas karakter seorang anak akan memberikan konsekuensi terhadap penilaian seorang ayah dan ibu. Sang guru hikmat bukan hanya kepada seorang ayah, namun juga seorang ibu. Oleh sebab itu, pendidikan dalam keluarga dilakukan oleh tim, yaitu ayah dan ibu (melihat Konteks Amsal 4:1;6:20; dan lain-lain). Ketiga, Penulis Amsal mengajarkan agar seorang anak dapat memiliki kualitas karakter yang bijak.

Kualitas karakter anak yang bijak diperoleh dari didikan orangtua. Melalui kajian penulis dalam Amsal10:1-5, anak yang bijak dididik dalam ajaran-ajaran moral yang bersumber pada ajaran Tuhan (konteks Perjanjian Lama). Selain itu, proses pendidikan juga didasarkan kepada pengalaman yang baik dari kehidupan seorang ayah dan ibu, sehingga seorang anak dapat meniru kebiasaan-kebiasaan/sifat-sifat baik dari orangtuanya, terlebih lagi sifat bijak yang ditekankan dalam Amsal 10:1-5 adalah sifat kejujuran (ay.3) dan ketekunan (ay. 4-5) sebagai suatu keidentikan seorang yang berakal budi. Dan keempat, tindakan ataupun karakter yang ditunjukan kepada seorang anak dapat menjadi suatu evaluasi bagi orangtua terhadap ajaran-ajaran hikmat yang telah disampaikan (Band. Ajaran hikmat dalam Amsal 10:1), sehingga pada waktu mendatang dapat mengajarkan kembali ajaran-ajaran hikmat bagi seorang anak, agar kelak dapat menjadi seorang anak yang bijak. 


\section{Daftar Pustaka}

Abrams, Meyer H. A Glossary of Literary Terms, edisi ke 4. New York: Holt, Rinehart\&Winston, 1981.

Alter, Robert. The Wisdom books: Job, Proverbs, and Ecclesiastes: a translation with commentary. London: W. W Norton \& Company, 2010.

Bauer, David R. Robert A. Traina. Inductive Bible Study: Langkah-langkah Praktis memahami Hermeneutik Alkitab. Yogyakarta: ANDI, 2017.

Brown, Francis, S. R. Driver, dan Charles A. Briggs. The Enhanced Brown-Driver-Briggs Hebrew And English Lexicon. Oxford: Clarendon Press, 1906.

Brown, William P. Character in Crisis: A Fresh Approach the Wisdom Literature of the Old Testament. Grand Rapids: William B. Eerdmans Publishing, 1996.

Fox, Michael. Proverbs 10-31: A New Translation With Introduction And Commentary. New Haven: Yale University, 2009.

Garrett, Duane A. The New American Commentary:An Exegetical and Theological Exposition of Holy Scripture Proverbs, Ecclesiastes, Song of Songs. Nashville: Broadman \& Holman Publishers, 1993.

Harris, R. Laird, Gleason L. Archer, Jr., Bruce K. Waltke, Theological Wordbook of the Old Testament. Chicago: Moody Press, 1981.

Henry, Matthew. Tafsiran Matthew Henry: Kitab Amsal. Surabaya: Momentum, 2013.

Holladay, William L. A Concise Hebrew And Aramic Lexicon of the Old Testament. Grand Rapids: Eerdmans; Leiden: Brill, 1988.

Keil, C. F, F. Delitzsch, Biblical Commentary on the Old Testament. Grand Rapids: Eerdmans Publishing, 1950.

Koesoema, Doni. Pendidikan Karakter Utuh dan Menyeluruh. Yogyakarta: Kanisius, 2015.

Licona, Thomas. Character Matters: How to Help Our Children Develop Good Judgement, Integrity, and other essential virtues. Jakarta: Bumi Aksara, 2012.

Longman III, Tremper. Making Sense of the Old Testament. Diterjemahkan oleh Cornelius Kuswanto. Disunting oleh Yusak P. Palulungan. Malang: Literatur SAAT, 2012.

McCreesh, Thomas P. Biblical Sound and Sense: Poetic sound patterns in Proverbs 10-29. Sheffield: Journal for the Study of the Old Testament, 1991.

Meynet, Roland. Rethorical Analysis: An Introduction to Biblical Rhetoric. Sheffield: Sheffield Academic Press, 1998. 
Miller, John W. Believers Church Bible Commentary: Proverbs. Pennsylvania: Herald Press, 2004.

Murphy, Roland E. The Wisdom Literature. Grand Rapids: Wm. B. Eerdmans Publishing Co, 1983. . Word Biblical Commentary Vol.22. Colombia: Thomas Nelson Publishers, 1998.

Owens, John J. Analytical Key to the Old Testament. Grand Rapids: Baker Books, 2000.

Ross, Allen P. The Expositor's Bible Commentary . Michigan: Zondervan, 2008.

Samani, Muchlas, Hariyanto. Konsep dan Model Pendidikan Karakter. Bandung: Remaja Rosdakarya, 2017.

Sandy, Brent Ronald L. Giese, Jr. Cracking Old Testament Codes: A Guide Interpreting the Literary Genres of the Old Testament. Nashville: Broadman \& Holman Publishers, 1995.

Setiawani, Stephen Tong. Seni membentuk karakter Kristen. Surabaya: Momentum, 2014.

Sinulingga, Risnawaty. Tafsiran Alkitab: Amsal 10:1-22:16. Jakarta:Gunung Mulia, 2012.

Toy, C. H. Critical and Exegetical Commentary on the Book of Proverbs. Edinburgh: T\&T Clark, 1904.

Waltke, Bruce K. The Book of Proverbs: Chapters 1-15 in The New International Commentary on the Old Testament. Grand Rapids: Wm. B. Eerdmans Publishing, 2004.

Whybray, R. N. Wealth And Proverty In The Book of Proverbs. Sheffield: JSOT Press, 1990.

\section{Jurnal}

Dave Bland, "The Formation of Character in The Book of Proverbs," Restoration Quarterly Jil. 40. 1998.

R. D. Vito, "Old Testament Anthropology and the Construction of Personal Identity" Catholic Bibliqal Quaterly 61.1999.

Sualang, Farel Yosua. "Analisa Sifat Kejujuran sebagai suatu Pembentukan Karakter menurut Amsal 10: 2-3."

Sualang, Farel Yosua. "Prinsip-Prinsip Hermeneutika Genre Hikmat dalam Kitab Amsal: Suatu Pedoman Eksegesis."

Ted Hildebrandt, "Proverbial Strings: Cohesion in Proverbs 10," Grace Theological Journal 11.2. 1990 . 


\section{Karya Ilmiah}

Sualang, Farel Yosua. "Studi Analisis Dan Sintesis Mengenai Pembentukan Karakter Melalui Harta Dalam Amsal 10: 1-22: 16." (2019). 